\title{
A Review of the Factors behind Academic Integrity Violations: Comparing the United States and Ukraine
}

\author{
Aaron M. Kennet
}

B.A., University of Maryland, Baltimore County, USA; Fulbright English Teaching Assistant (2017-2018), Sumy State University, Ukraine

\section{Yuliia Shkodkina}

PhD, Assistant Professor, Department of Finance and Entrepreneurship, Sumy State University, Ukraine

\begin{abstract}
Recently, there has been a rapid growth of articles on academic integrity issues in Ukrainian scholarly publications, however, few of them have focused on factors of academic dishonesty. To develop an effective academic integrity policy, it is necessary to conduct preliminary research into the factors and reasons of academic dishonesty. Extensive research related to reasons and factors of academic dishonesty has been conducted in other countries, but not yet for a Ukrainian context.

This article aims to provide a literature review on the reasons for academic dishonesty and factors leading to academic integrity violations. The article shows the key directions of research on the factors of academic dishonesty that have been studied among American students, using articles primarily from US academic literature and comparing them to relevant, available Ukrainian scholarly publications. Though the review does not claim to be a fully comprehensive one, it does provide an overview of the scale of factors and the variety of reasons for academic dishonesty in Higher Educations Institutes (HEIs).
\end{abstract}

Literature was retrieved from Scopus, ResearchGate, Google Scholar databases, and Springer journals by using key search words such as factors of, reasons or causes for academic dishonesty, academic misconduct, academic integrity violation and unethical academic behaviour.

The review showed that there are numerous reasons for academic integrity violations and that they stem from two major groups of factors - internal individual and external contextual factors. Whether it is beyond or within the bounds of possibility that a factor can be changed and accordingly utilized depends on its nature external or internal - towards a student, and level (scale) of its influence - national, institutional or individual. An overview of available studies on factors behind academic dishonesty in Ukrainian HEIs demonstrated which factors need more detailed and extensive research to provide a sound base for developing an effective academic integrity policy. The findings of the article contribute to a deeper understanding of the most significant reasons students might have for committing academic malpractice, and to help develop academic integrity policies in Ukrainian institutions.

Keywords: academic integrity, academic dishonesty, academic misconduct, violation, factors, reasons.

JEL Classification: I23, I29.

(C) The Authors, 2018. This article is published with open access at Sumy State University.

\section{Introduction}

There has been a growing research interest in issues related to academic integrity in Ukraine, partly due to the development and adoption of a new law on education that specifically addresses academic integrity, and partly due to the increasing number of reported incidents of academic misconduct on the national level. Ukrainian higher education institutions have introduced numerous rules and regulations - in particular honor codes without conducting preliminary research into the reasons for academic integrity violations. To develop effective academic integrity policy, understanding the factors that influence academic behaviour is needed. Students' reasons for academic misconduct either in the form of cheating or plagiarism depend on various and numerous factors - individual or personal, contextual or situational, environmental, cultural and academic, which have yet to been examined for students in Ukrainian HEIs. Having a history of dealing with academic dishonesty for an extensive period of time - according to American researchers' estimates discussions on academic integrity issues have been taking place for 50-70 years (Romakin, V. V., 2010) - the USA is one of the best examples to consider the directions of research into the reasons for the violation of academic integrity. 
For the purpose of this article we refer to the concept of academic integrity as a set of "ethical principles and rules stipulated by the law, which should be followed by participants of the educational process during study, teaching and implementation of scientific (creative) activities in order to ensure confidence in learning outcomes and/or scientific (creative) achievements" (Zakon Ukrayiny Pro Osvitu [Law of Ukraine on Education], Article 42). According to the International Center for Academic Integrity, academic integrity implies a commitment to six fundamental values, such as honesty, trust, fairness, respect, responsibility, and courage, even in the face of adversity (Statistics of International Center for Academic Integrity). Whereas academic dishonesty is considered as the fundamental problem for academic integrity (Romakin, V. V., 2010). Since the terms "academic dishonesty", "academic misconduct", "academic cheating", "cheating", "cheating behaviour" or situation, "disintegrity", according to (Salgado, J. F., Moscoso, S., Sanchez, J. I., Alonso, P., Choragwicka, B., \& Berges, A., 2014: 5) "overlap each other with similar meaning", we utilize them interchangeably for describing violations of academic integrity.

\section{Methods}

Literature was retrieved by using key search words such as factors of, reasons or causes for academic dishonesty, academic misconduct, academic integrity violation and unethical academic behaviour. Primarily American scholarly publications were reviewed, most of which are referenced in the literature review. For search of relevant articles the following databases were used: Scopus, ResearchGate, Google Scholar, and Springer journals.

\section{Overview of academic dishonesty incidence in the US and Ukraine}

Academic dishonesty has been a problem in higher education in the USA for decades. In the 1990's, 60-70\% of American students engaged in at least one form of academic dishonesty (Whitley, B. E. Jr., 1998). Review of (Whitley, B. E. Jr., 1998) showed that about $47 \%$ of college students had plagiarized, $43 \%$ had cheated during their exams, $41 \%$ had cheated in their home assignments. More recent surveys have confirmed earlier findings. In 2005, one of the most comprehensive study of academic integrity was conducted (McCabe, D.L., 2005), within which about 50000 students from more than 60 American universities were surveyed, and revealed that $70 \%$ of students had involved in some form of academic integrity violation. Whereas results of the survey (Statistics of International Center for Academic Integrity), conducted in 2011, reported approximately $80 \%$ of students, who had admitted to cheating at least one time during their studies at the university. In general, the statistics for two-thousands and partly for two thousand and tens on cheating among American students indicate that academic dishonesty is still a serious problem for HEIs in the USA. According to research carried out by D. McCabe and the International Center for Academic Integrity between 2002 and 2015, demonstrating general trends of almost 13 years based on the surveys of more than 88000 students, $43 \%$ of graduate and $68 \%$ of undergraduate students had admitted to cheating on tests or written assignments (Statistics of International Center for Academic Integrity).

What is most remarkable is that academic dishonesty takes place in all HEIs in the USA, regardless of their ranking and these instances are not isolated. Even top American universities admit to having a cheating or plagiarism problem. To name a few, Harvard University, Stanford University, the University of North Carolina and even the University of Virginia that is famous for its Honor System, have faced cheating scandals and investigated violations of their academic honor codes in past years, upon which students have been expelled or forced to withdraw for some period of time (Iaboni, R., 2013; Lindsay, R., 2015; Lyall, S., 2014).

As far as statistics of academic dishonesty in Ukraine are concerned, only a few studies have been conducted into the topic so far. Findings of research (Bakirov, V.S., 2015) carried out in 2014-2015 among more than 2000 respondents demonstrate that $90 \%$ of Ukrainian students engage in plagiarism during their time at the university; $78 \%$ of students pass exams with some assistance, $67 \%$ of whom cheat on the exams; and $23 \%$ think that there are cases of getting grades for some services or money at their institutes. A more recent study of the Project for Strengthening Academic Integrity in Ukraine - the project of American Councils for International Education - in cooperation with CEDOS conducted at the end of 2016 in which 3000 students from 10 Ukrainian institutes were surveyed, shows that on average $62 \%$ of students think that there is no practice of negotiating with the faculty or administration about grades in return for some services or money, hence, the rest - about 38\% - assume the existence of such academic malpractice (Strengthening Academic Integrity in Ukraine Project, 2016).

Undoubtedly academic dishonesty remains an important issue in both Ukraine and the United States. However, academic integrity violations in American universities are less frequent than in Ukrainian ones. In research (Romakin, V. V., 2010), comparing academic behaviour of students from one university in the USA and one in Ukraine, 378 students - 189 from each university - were asked about different forms of academic 
dishonesty they were involved during their studies. The results showed a significant difference between American and Ukrainian students as for all forms of academic integrity violations: twice as many interviewed Ukrainian students admitted to cheating on home assignments, accounting for $72 \%$ in comparison to $30,7 \%$ of interviewed American students; almost five times more Ukrainian students admitted to plagiarising from the Internet $-77,7 \%$ of Ukrainians as opposed to $16,5 \%$ of Americans; and cheating on exams at university were more than seven times higher $-81,9 \%$ of Ukrainians admitted to engaging in the practice as opposed to $11,1 \%$ of Americans (Table 1).

Table 1. Comparison of incidence of academic integrity violations in the US and Ukrainian universities

\begin{tabular}{|c|c|c|}
\hline \multirow{2}{*}{ Academic integrity violations } & \multicolumn{1}{|c|}{ Percentage of students who admitted violating academic integrity } \\
\cline { 2 - 3 } & \multicolumn{3}{|c|}{ Cheating on home assignments } \\
\hline \multirow{2}{*}{ Ukraine } \\
\hline - cheating from other students & $30,7 \%$ & $72 \%$ \\
\hline - forbidden assistance & $50,3 \%$ & $83 \%$ \\
\hline \multicolumn{2}{|c|}{ Plagiarism } \\
\hline - from books or articles & $16,5 \%$ & $57,4 \%$ \\
\hline - from the Internet & Cheating on tests or exams & $77,7 \%$ \\
\hline \multicolumn{2}{|c|}{$22,3 \%$} & $64,7 \%$ \\
\hline - peer cheating & $11,1 \%$ & $81,9 \%$ \\
\hline - using cheat sheets & &
\end{tabular}

Source: Romakin, V. V., 2010

Earlier findings of cross-national analysis of academic dishonesty (Grimes, Paul W., A., 2003) among high school students in the US and Ukraine supported the difference in probability of academic cheating between American students and their Ukrainian peers. The percentage of high school students in Ukraine who had cheated and who had been asked to cheat, appeared to be greater compared to the US students. In comparison to American high school students, their Ukrainian peers would have assisted in academic cheating almost two times more - 44,65\% to 86,52\% - and Ukrainian students considered cheating ethically wrong two times less $-68,72 \%$ and $34,27 \%$ respectively. Hence, more than $65 \%$ of high school students in Ukraine found it socially acceptable (Figure 1 ).

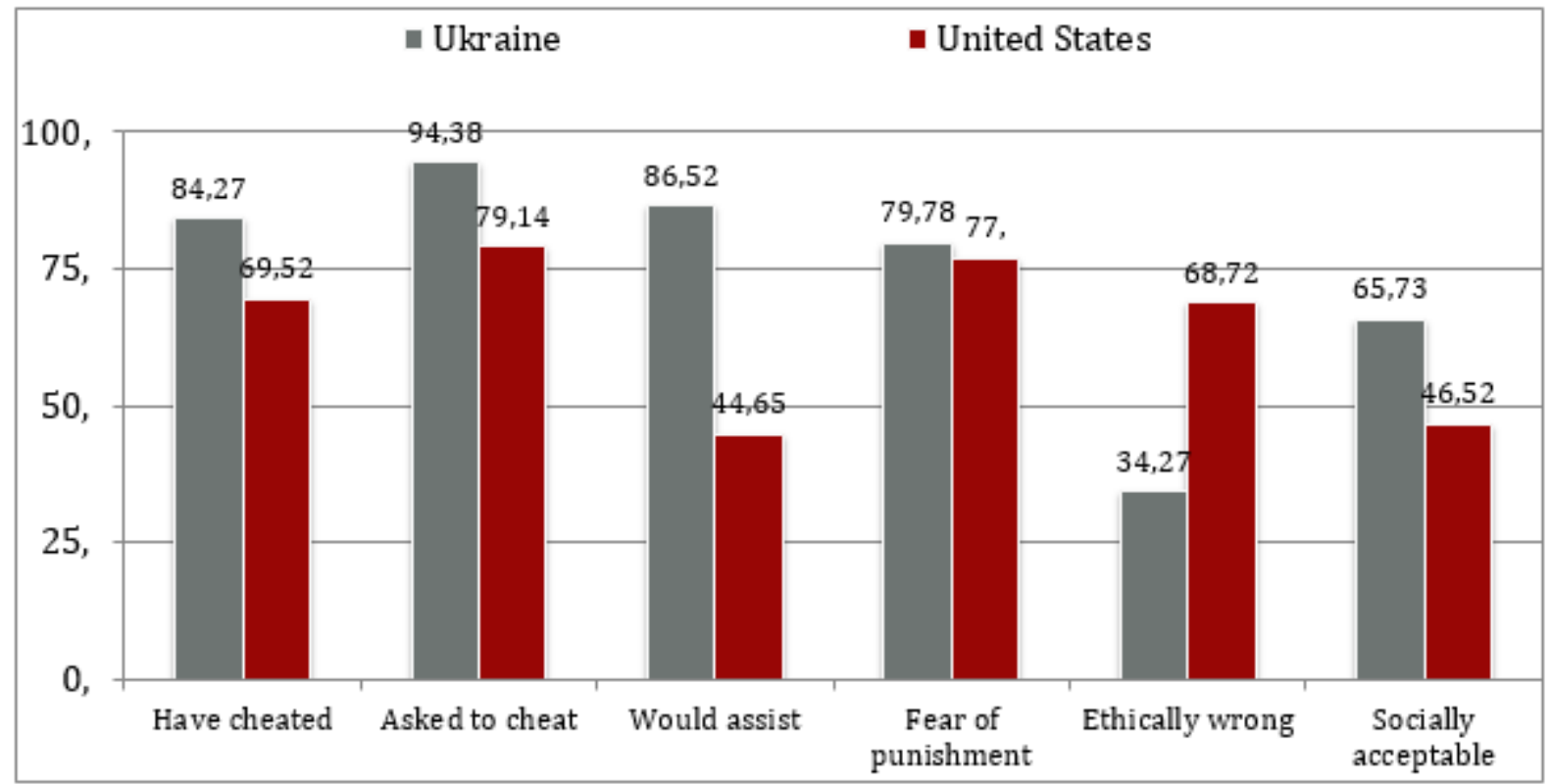

Figure 1. Comparison of self-reported incidence and perceptions of academic cheating among high school students in the USA and Ukraine

Source: Grimes, Paul W., A., 2003 
What is more important, is that the findings of the research (Romakin, V. V., 2010) provided a snapshot of attitudes towards academic dishonesty in both American and Ukrainian universities, which appeared to be rather different, sometimes even opposite. For instance, most of the surveyed Ukrainian students found cheating excusable if a professor was bad at teaching or left a classroom, while their American peers considered it absolutely unacceptable in most cases (Romakin, V. V., 2010). In general, about 50\% of students in Ukrainian HEIs find a reason for occasional cheating, and that depends on the professor as well as the situation. Approximately $30 \%$ more find cheating absolutely acceptable, which in total accounts for on average $80 \%$ of Ukrainian students who consider academic cheating an acceptable practice (Figure 2) (Strengthening Academic Integrity in Ukraine Project, 2016).

Unacceptable

Occasionally yes, it depends on a professor and situation Entirely acceptable

Difficult to answer

\section{Cheating during intermediate tests}

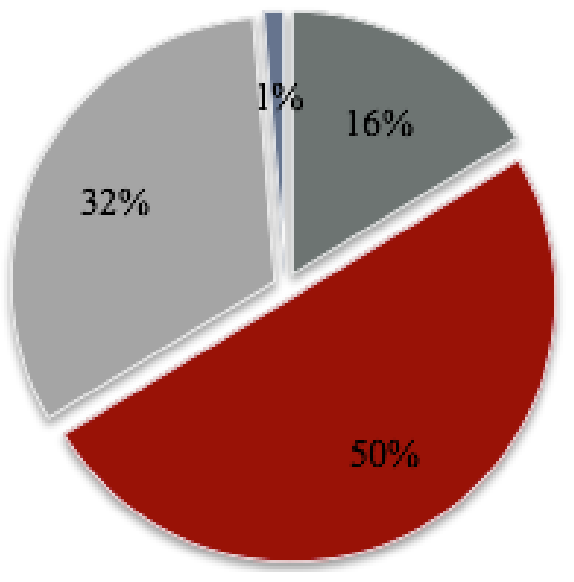

Unacceptable

Occasionally yes, it depends on a professor and situation

Entirely acceptable

Difficult to answer

Cheating during final examinations

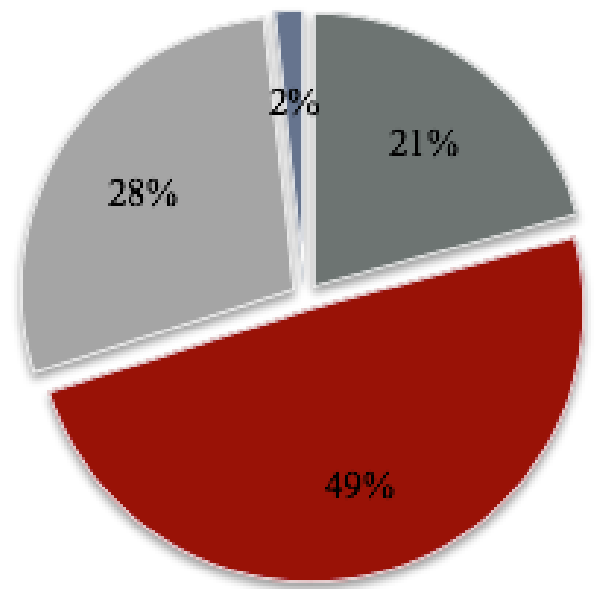

Figure 2. Cheating from personal notes

Source: Strengthening Academic Integrity in Ukraine Project, 2016

Therefore, to effectively prevent academic dishonesty in Ukrainian HEIs, it is necessary to have both an understanding of the reasons behind academic integrity violations as well as understanding of the influence of different factors on the students.

\section{Results}

There are numerous reasons for the violation of academic integrity, which vary based off of situation and institution, and stem from two major groups of factors - internal individual and external contextual factors. The first group of factors addresses personal reasons, characteristics, and motivation for academic misconduct. Factors of the second group relate to pressures imposed upon a person by a national system of higher education, an institution's policy and procedures for academic integrity, peers, and associated pressures. In turn, external factors might be situational or occasional.

There are various personal reasons for violating academic integrity principles during the educational process, with great emphasis being placed on cheating and plagiarism. Studies conducted by different researchers in the United States of America reveal that students engage in academically dishonest practices due to performance - the need to get better grades (Cummings, R., Maddux, C. D., Harlow, S., \& Dyas, L., 2002; Jones, D. L. R., 2011; Szabo, A., \& Underwood, J., 2004); procrastination (Jones, D. L. R., 2011; Roig, M., \& Caso, M., 2005; Synder, L. G., \& Cannoy, S. D., 2010); ignorance (Jocoy, C., 2006; Pickard, J., 2006); in pursue of a good job (McCabe, D. L., Trevino, L. K., and Butterfield, K. D., 2001; Miller, A. D., Murdock, T. B., Anderman, E. M., \& Poindexter, A. L., 2007); the Internet (Baum, J. J., 2005; Bruster, B., 2004), lack of motivation to study (Heuser, B.L. \& Drake T.A., 2011); poor moral reasoning (Szabo, A., \& Underwood, J., 2004), etc. 
During the nineties, US investigation of academic dishonesty factors included research into personal characteristics, such as age, gender, religiosity, family financial background (Allmon, D.E., Page D., Roberts, R., 2000; Ballantine, J., Larres, P. M., 2012; McCabe, D. L., \& Trevino, L. K., 1997; Nonis, S., \& Swift, C.O., 2001; Whitley, B. E. Jr., 1998), assuming that men are more prone to unethical academic behaviour or that younger students are more likely to commit academic malpractice. More recent studies of $2002-2004$ support these correlations, concluding that men were cheating more than women - 68\% against $39 \%$ respectively; and that students in their first or second year at the university were more likely to cheat comparing to students in their third year (Brown, D. L., 2002; Whitley, B. E. Jr., 1998).

Over the last decade, researchers have paid more attention to the role of personality in violating academic behavior, examining the Big Five factors - neuroticism, extraversion, openness to experience, agreeableness, and conscientiousness (Clariana, M., 2013; Giluk, T.I., Postlethwaite, B.E., 2015; Salgado, J. F., Moscoso, S., Sanchez, J. I., Alonso, P., Choragwicka, B., \& Berges, A., 2014; Williams, K. M., Nathanson, C., \& Paulhus, D. L., 2010). However, the results of studies in this area are quite controversial, showing opposite relationships between mentioned personality factors and academic dishonesty.

Some more personal characteristics that have only recently become key factors of academic dishonesty being examined, are cultural background and/or the country of origin of students (Lupton, R. A., Chapman, K. J., Weiss, J. E., 2000; Magnus, J. R., Polterovich, V. M., Danilov, D.L., Savvateev, A.V., 2002). The assumption is that international students are particularly likely to violate academic integrity rules, notably by plagiarising. However, other forms of academic misconduct, such as cheating, unauthorized help, using Internet paper mills and others, take place quite often among foreign students. The findings of an analysis conducted (Jordan, M. \& Belkin, D., 2016) among students enrolled at US public universities showed that international students usually cheat more often than their domestic counterparts: there were about five reports of alleged cheating for every 100 foreign students and only one for every 100 domestic students during the $2014-2015$ academic year. It was also reported that students from China appeared to be the most frequent violators.

The relationship between the future profession of students and their inclination towards academic dishonesty has been the area of research interest for years in US scholarly articles, addressing business students (McCabe, D. L., Butterfield, K.D., \& Trevino, L. K., 2006; Nonis, S., \& Swift, C. O., 2001; Wood, J. A, \& Longenecker, J. G., 1988); engineering students (Harding, T. S., Carpenter, D. D., Finelli, C. J., \& Passow, H. J., 2004); psychology (Lucas, G. M., \& Friedrich, J., 2005) or nursing students (LaDuke, R., 2013), etc. Students of business are reported to be the least honest in academia, showing the highest rate of cheating in comparison with engineering, science and humanities students (Harris, J. R., 1989; McCabe, D. L., \& Trevino, L. K., 1997). According to study (McCabe, D. L., \& Trevino, L. K., 1997), which is based on data from almost 2000 undergraduates at sixteen HEIs in the US, $91 \%$ of business students admitted to engaging in any form of cheating compared to $82 \%$ of engineering students, $73 \%$ of social science students, and $71 \%$ of students studying natural sciences. Though more recent studies indicate that business students cheat as others - no more, no less (Klein, H. A., Levenburg, N. M., et al., 2007). Other scholars argue that engineering students show higher cheating rates than students in most other majors, in particular than natural science and social science majors (Harding, T. S., Carpenter, D. D., Finelli, C. J., \& Passow, H. J., 2004; McCabe, D. L., \& Trevino, L. K., 1997). In turn, natural science students demonstrate cheating rates of the level comparable to social science students.

Another personal factor that was widely examined with respect to its impact on academic dishonesty is motivation (Angell, L. R., 2006; Jordan, A.E., 2001; Murdock, T.B., Miller, A., \& Kohlhardt, J., 2004), which typically is considered in two dimensions - depending on mastery or performance goals. Mastery goal orientation relates to a desire to learn or master the subject and is inherent to students who are less prone to cheating. Students driven by performance goals, such as grades and academic ranking, are more likely to cheat. Thus, mastery goal orientation leads to the strengthening of academic integrity, whereas performance goal orientation provokes violations of academic integrity norms (Jordan, A.E., 2001; Murdock, T.B., Miller, A., \& Kohlhardt, J., 2004). There are numerous studies into students perceptions, beliefs and attitudes towards academic dishonesty (Callahan, D., 2004; Del Carlo, D. I, \& Bodner, G. M., 2003), which have been considered as influential factors as well.

When it comes to Ukraine, so far there have been few scholarly studies conducted into the reasons for violating academic integrity among students at Ukrainian institutions and the factors influencing them. Most of these 
studies are focused on the factors at the institutional level - dependent on rules and regulations established by a higher education institution (honor codes and ethical guidelines, curricula and syllabi, assessment procedures and methods, etc.), and on the factors at the national level - those that depend on the higher education system and related policies on a national level, such as massification of higher education, limitations in legislation, weak tradition of academic culture, etc.

As far as personal or individual factors are concerned for engaging in or restraining from academic integrity, only motivation has been studied among students at Ukrainian institutions. Emphasizing mastery goal orientation and performance goal orientation, Ukrainian students are as goal oriented as American ones, but the latter appeared to care more about their performance (Romakin, V. V., 2010). However, findings of a more recent study (Bakirov, V.S., 2015) showed that the overwhelming majority of Ukrainian students is oriented more on formal features of higher education, such as grades, scholarship, and completion of their diploma, rather than on obtaining professional knowledge.

According to an OECD report (OECD, 2017), weak intrinsic motivation to study among Ukrainian students is observed even on the stage of considering an institute for bachelor studies: candidates choose subjects for the external standardised test, which will be easier to pass and to get a higher score. A questionnaire held in 2015 (Bakirov, V.S., 2015) about the reasons to enter higher education institution among 2000 Ukrainian students, supports this, showing only one option addressing intrinsic motivation for studying - "to obtain knowledge and become a good professional", which was selected by only $62 \%$ of student respondents. Whereas all the rest of the answers referred to extrinsic reasons, such as finding a job, the opportunity for a better salary and living an independent life, the improvement of social status, obtaining a better reputation, etc. According to the annual International Student Survey over last the several years with more than 60000 students from 65 universities around the world interviewed, the top reasons for entering a higher education institution appeared to be passion about the subject and the continuation of learning and development, accounting for $58,4 \%$ and $58 \%$ respectively (International Student Survey, 2017). The list of reasons included extrinsic reasons as well, such as a desire for a particular career, better job or job opportunities, greater sense of freedom, etc. However, in addition to the first two reasons, there were more intrinsic reasons demonstrating motivation to study, such as "to be intellectually challenged and stimulated", because "university is the natural progression after school".

One more factor that has been found to be the reason for violating academic integrity norms by students at Ukrainian institutions, is the lack of awareness of academic integrity issues. Undergraduate and postgraduate students in Ukraine lack knowledge of academic and research ethics, having insufficient and fragmentary awareness of terms and rules of proper academic conduct and of possible penalties that might be imposed for committing academic misconduct (Polotska, O. O., 2016). This is rooted in high school years, where being asked to cheat by classmates and cheating itself have been socially acceptable in Ukraine. Personal beliefs about the ethics and social acceptability of cheating are found to positively affect the probability of academic misconduct in high school, especially in transitional economy such as Ukraine (Grimes, Paul W., A., 2003).

However, we consider lack of students' awareness of academic integrity standards as an institutional factor and the personal belief that cheating is socially acceptable as a factor of the national level, since it forms in primary and secondary school and leads to a weakly developed culture of academic integrity, which creates incentives for violating the latter (OECD, 2017).

Most of the institutional factors provoking academic dishonesty among students at Ukrainian institutions relate to plagiarism, which is believed to be the most common form of academic integrity violations in Ukraine (OECD, 2017). Students at Ukrainian institutions are assumed to plagiarize due to out-of-date or non existent syllabi and overloaded curricula, in particular with written assignments; the results of assignments that are non-applicable to practice and unconnected to the modern needs of the labour market; the lack of understanding of the need and purpose for writing and completing some assignments; vulnerable assessment methods and procedures; the HEI's faculty's tolerance of plagiarism and its low level of professionalism; an absence of clear and universal ethical norms (Bakirov, V.S., 2015; European Research Association, 2013; OECD, 2017; Stechenko, O. V., 2016). The most popular reason for plagiarism among Ukrainian students in 2016 appeared to be the overload of home assignments that are due during a semester or year (Figure 3). Overall, curricula and syllabi at HEIs in Ukraine require reconsideration and redesign to reduce their pressure on students and to lessen plagiarism. 


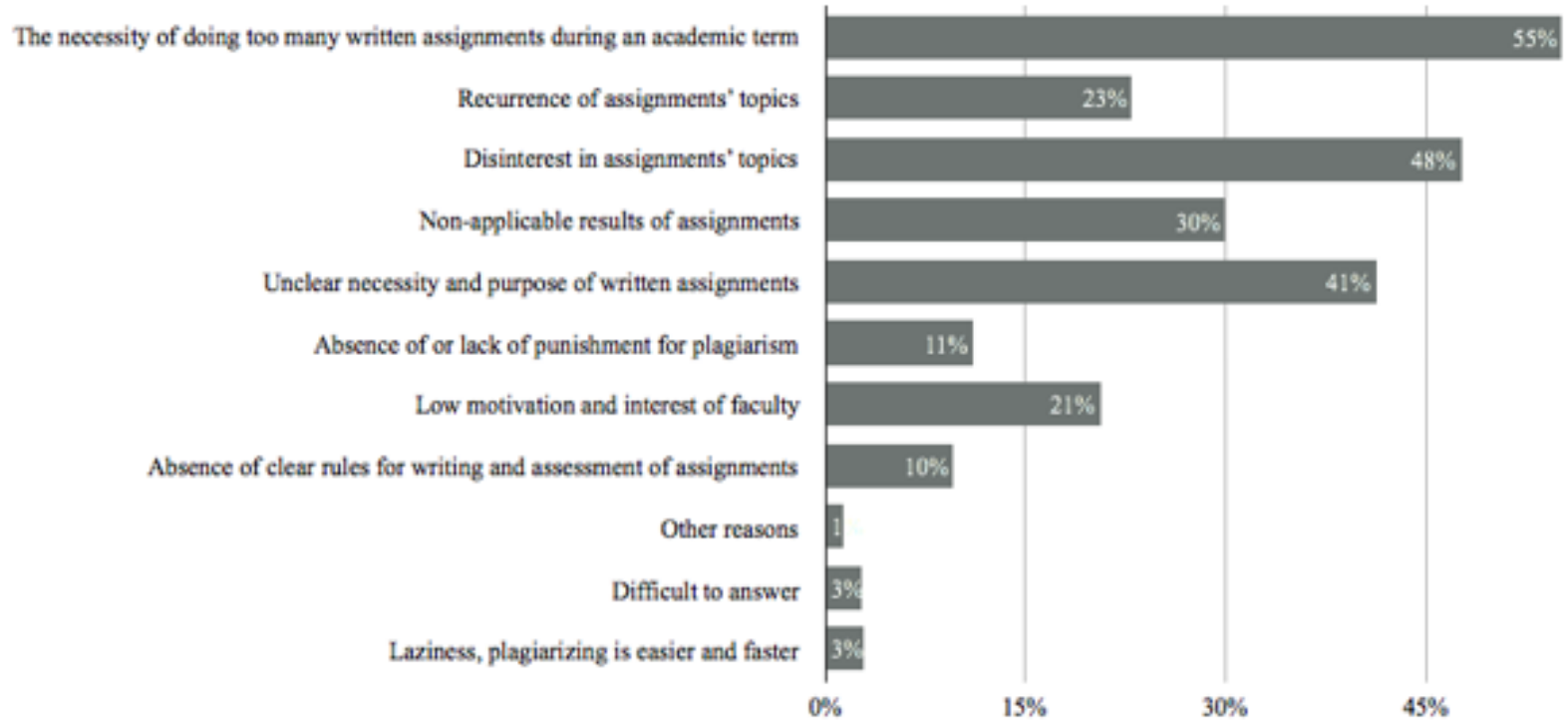

Figure 3. Reasons for plagiarizing among Ukrainian students

Source: Strengthening Academic Integrity in Ukraine Project, 2016

The absence of established ethical norms, codes of conduct or ethical guidelines has attracted a lot of attention in Ukrainian HEIs during last years, resulting in the adoption of university honor codes. As of April 1, 2016, out of the websites of 172 universities that were monitored within the study (Analitychna dovidka, 2016), only 27 HEIs had honor codes for students or its equivalents, published on their websites, and even fewer HEIs - 19 universities - had codes of ethics or their equivalents for pedagogical activities (Figure 4). Even though those 27 and 19 honor codes exist in university publications and websites, in practice, very few of them function effectively and lead to case consideration with sanctions applied, because there is no adequate training based on the new norms in some institutions or there are different penalties for academic dishonesty among faculties and departments of the same university (OECD, 2017).
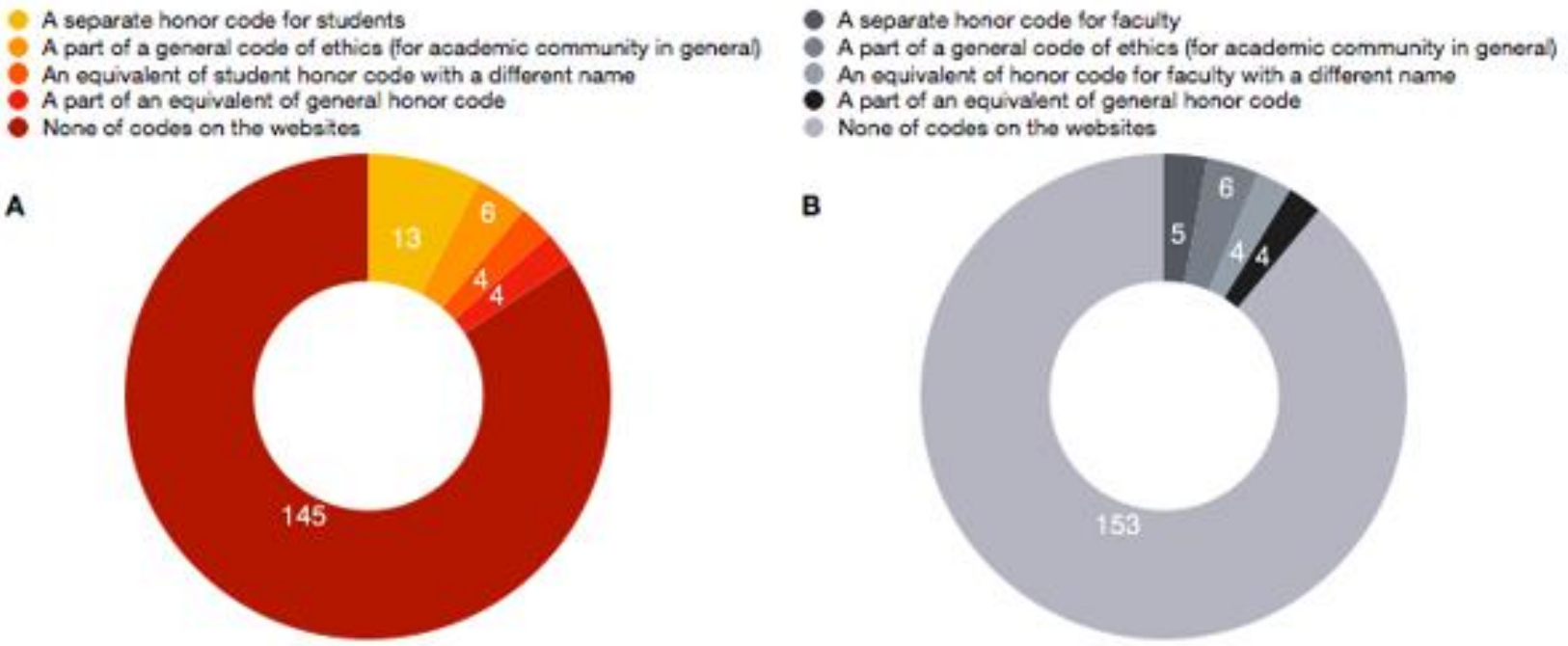

Figure 4. Availability of honor codes for students (A) and for faculty (B) on the websites of Ukrainian HEIs

Source: Analitychna dovidka, 2016

Furthermore, in Ukraine there have been almost no cases when sanctions for academic dishonesty were imposed, whereas in the United States violations of academic integrity at the university may influence professional lives of violators long after graduation. There are numerous examples of high-ranking officials, whose career paths have changed drastically since plagiarism was identified in their dissertations or other degree theses. This list includes former Vice-President of the USA, Joe Biden, whose presidential campaign of 1988 ended after a potent plagiarism scandal. In 2016, CNN even made a list comprising the most famous public scandals regarding plagiarism, committed by politicians (Denisova-Schmidt, E., 2016; Fawzy, F., 2016). There have been plagiarism scandals about dissertations of Ukrainian officials as well, but none of them led to a correspondent penalty. 
Regarding factors provoking academic dishonesty at the institutional level in the USA we would consider poor professors and teaching environments (Anderman, E. M., 2007; Hinman, L. M., 2002); inadequate policies and penalties regarding academic dishonesty (Macdonald, R., \& Carroll, J., 2006; Martin, D. F., 2005); peer influence (Del Carlo, D. I, \& Bodner, G. M., 2003; Petress, K. C., 2003); cheating culture (Callahan, D., 2004; Langlais, P. J., 2006; Vojak, C., 2007), etc. However, many of these factors might be situational per se. As one of the special and most challenging institutional factor we would consider HEI's leniency for athletes, who get credit for classes unfairly. In pursuit for students-athletes, at some institutes a "shadow curriculum" is developed, which implies fake classes and/or too small workload for students to pass (NCAA should punish the University of North Carolina for cheating scandal, 2014). Two prime case studies of the difficulties regarding academic integrity in sports programs in the US are the case at Syracuse University and the University of North Carolina at Chapel Hill. At Syracuse University administrators held a complete list of student-athlete emails and passwords, and had tutors complete the work for athletes, and would directly email assignments to the professor using student accounts (Solomon, J., 2015). At the University of North Carolina, students were enrolled in "phantom classes", which didn't actually exist, and were given high marks for nonexistent classes, and non-existent academic work (Lyall, S., 2014).

In most cases violations of academic integrity at the institutional level occur due to the lack of scrutiny by administrators, who might be rather optimistic about academic integrity issues at their institutions. A study (Brown, B.S., Weible, R.J. \& Olmosk, K.E., 2010) aimed at identifying perception of the extent of academic dishonesty at several American business schools by its deans, revealed that only 5,1\% of deans considered academic dishonesty as a serious problem in the institutions they worked and $78 \%$ of deans believed that fewer than $40 \%$ of students engaged in academic misconduct.

According to (Marsden, H., Caroll, M. \& Neill, J., 2005) there is a strong relationship between the influence of situational factors and academic dishonesty. Situational factors like peer behaviour and peer disapproval play an important role in students' attitudes and perceptions of cheating (McCabe, D. L., \& Trevino, L. K., 1997). The need for approval stands by these factors, because students who need approval are more likely to engage in unethical behaviour. This is why peer influence is widely examined as a factor of violating academic integrity among American students (Del Carlo, D. I, \& Bodner, G. M., 2003; Petress, K. C., 2003) and a student's peer group is considered to be one of the most influential factor (McCabe, D. L., Trevino, L. K., and Butterfield, K. D., 2001).

A survey (Hendershott, A. Drinen, P. \& Cross, M., 2000) found that students believed it was an institution's role to monitor the behaviour of other students, rather than by their peers. Later in the study (Rabi, S. M., Patton, L. R., Fjortoft, N., \& Zgarrick, D. P., 2006) it was revealed that $65 \%$ of students would not report a course mate who cheated, which might be a concern for certain professions. For instance, professionals in such spheres as nursing or pharmacy are obliged to report unethical, dishonest behaviour under codes of conduct within the profession.

Reviews of integrity in education in Ukraine in 2017 (OECD, 2017) revealed factors in the system that create opportunities for academic integrity violation on a wide scale. Primarily the list focuses on limitations in legislation, and a sense of impunity for acts of academic dishonesty. As for the former with the adoption of the new Law of Ukraine "On Education" in September 2017 some limitations in legislation have been lowered: a term of academic integrity and its definition were introduced on the federal level, forms of violations of academic integrity and sanctions for them. As for what constitutes a violation of academic integrity, the legislation is absolutely precise: academic plagiarism, self-plagiarism, fabrication, falsification, cheating, deceit, bribery and biased assessment. But when it comes to sanctions for violating academic integrity, the law forwards to the specific laws and/or to internal regulations of the unique HEIs, leaving the responsibility to the latter and, hence, decentralizing penal actions. In this respect, the sense of impunity for acts of academic dishonesty should be considered amongst institutional factors.

In the United States, there is no singular attitude or approach to academic integrity. While legally, copyrights are protected and plagiarism is punishable (17 United States Code, $\S 102,1990 ; 17$ United States Code $§ 401$, $405,1988)$, there are no specific standards established by the Department of Education to attempt to define a concept of academic integrity. Each university has a separate academic code, implemented according to the norms and rules of each individual institution. This decentralized format has caused institutions to behave and react differently on all fronts: some institutes utilize an arbitration policy (Policy and Procedures for Student Academic Misconduct); and some operate based off of a situational decision-making paradigm (Student Guide to Academic Integrity Policies and Procedures). This application of policy depends entirely on the severity of the academic infringement, however these tools are still employed as methods of addressing issues related to 
violation of academic standards. In all cases, there is a clear absence of centralized penal action taken to address these issues.

Therefore, there are numerous and various factors of violating academic integrity principles, regardless of the country. Nevertheless, scholarly publications reviewed for this article show the lack of research into the factors of academic integrity violations by students in Ukrainian HEIs. Most of the studies revealed reasons for academic dishonesty in Ukrainian HEIs, mentioning factors which might be behind them, though, they omit research into the influence or impact of these factors on the decision to engage in academic misconduct or not (Table 2). The summarizing Table 2 does not claim to be comprehensive, however, it gives a general overview of which factors need more detailed and extensive research to have a sound base for developing academic integrity policies in separate Ukrainian HEIs.

Table 2. Overview of academic dishonesty factors being mentioned and/or studied in scholarly publications for Ukrainian HEIs

\begin{tabular}{|c|c|c|c|}
\hline \multirow{2}{*}{ Group of factors } & \multirow{2}{*}{ Examples of factors in a group } & \multicolumn{2}{|c|}{ Availability for Ukrainian context } \\
\hline & & Mentioned & Studied \\
\hline \multicolumn{4}{|l|}{ INTERNAL INDIVIDUAL FACTORS } \\
\hline Personal characteristics & $\begin{array}{l}\text { Age, gender, grade point average, } \\
\text { religiosity, cultural and financial } \\
\text { background, ete. }\end{array}$ & - & - \\
\hline Personality & $\begin{array}{l}\text { Openness, harm avoidance, self- } \\
\text { control, agrecableness, } \\
\text { conscientiousness, etc. }\end{array}$ & - & - \\
\hline Moral reasoning & $\begin{array}{l}\text { Beliefs, attitudes towards academic } \\
\text { dishonesty }\end{array}$ & {$[63 ; 69]$} & {$[22 ; 63]$} \\
\hline Motivation & $\begin{array}{l}\text { Goal orientation to better grades, } \\
\text { academic ranking or job prospects }\end{array}$ & {$[2 ; 5 ; 56 ; 63 ; 69]$} & {$[5 ; 56 ; 63 ; 69]$} \\
\hline Awareness of academic integrity issues & $\begin{array}{l}\text { Knowledge and understanding of } \\
\text { academic ethical rules and } \\
\text { penalties for breaking them }\end{array}$ & {$[60 ; 69]$} & [69] \\
\hline \multicolumn{4}{|l|}{ EXTERNAL CONTEXTUAL FACTORS } \\
\hline Institutional level & $\begin{array}{l}\text { HEI's rules and guidelines, rewards } \\
\text { and penalties, curricula \& syllabi; } \\
\text { assessment procedures and } \\
\text { methods, etc. }\end{array}$ & {$[5 ; 56 ; 19 ; 68 ; 69]$} & {$[2 ; 56]$} \\
\hline National level & $\begin{array}{l}\text { Massification of higher education, } \\
\text { limitations in legislation, poor } \\
\text { tradition of academic integrity }\end{array}$ & {$[5 ; 56]$} & {$[56]$} \\
\hline Occasional (situational) factors & $\begin{array}{l}\text { Peer behavior and influence, } \\
\text { computer internet technologies, etc. }\end{array}$ & - & - \\
\hline
\end{tabular}

Nonetheless, studies into some factors might have not practical implications for purpose of framing an academic integrity policy, since they cannot be changed or their influence cannot be eliminated. Whether it is beyond or within the bounds of possibility that a factor can be changed and accordingly utilized depends on its nature - external or internal - towards a student, and level (scale) of its influence - national, institutional or individual (Figure 5). Research into factors at the institutional level are of most importance for separate institutions, since this allows the institution to frame or adjust its academic integrity policy in the most effective way. For instance, knowing that low awareness of academic integrity rules is the most significant factor of academic dishonesty means that academic integrity needs more promotion in an institution; if future profession plays a dominant role - academic integrity rules should be differentiated for different specialities; in case of peer behavior's biggest impact - approaches to student groups formation require revision, etc. There are factors that can be changed, but are beyond the power or authority of an institution — factors of national level, such as limitations in legislation, poor tradition of academic integrity, etc.; individual motivation, beliefs and attitudes towards academic dishonesty. Last but not least, there are factors that might form reasons for academic misconduct, but cannot be changed by any authorities: inevitable development of internet and computer technologies or inherent personality and personal characteristics, such as age, gender, openness, selfcontrol, etc. 


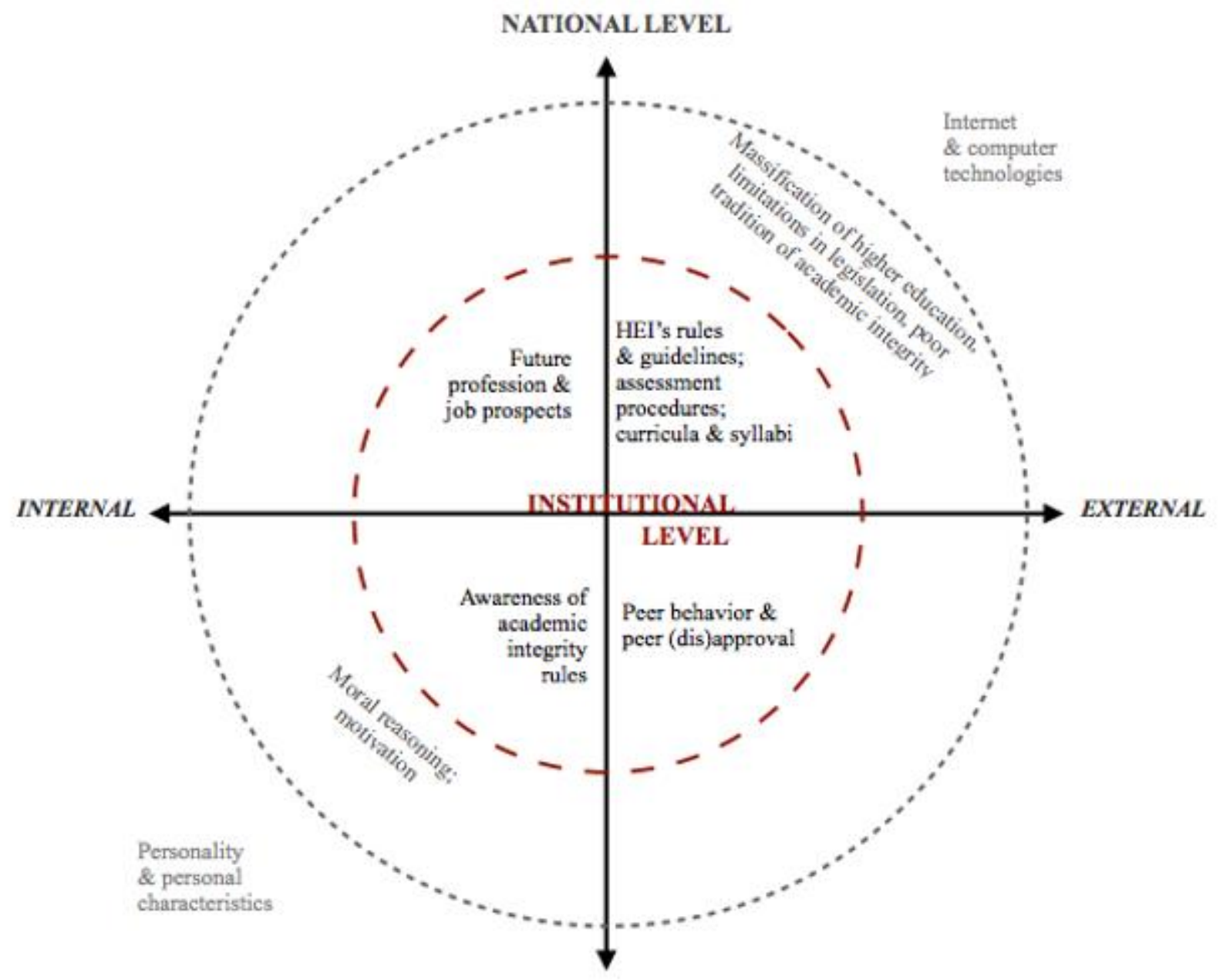

INDIVIDUAL LEVEL

Figure 5. Mapping of factors of academic dishonesty

\section{Conclusions and Recommendations}

There is a lack of scholarly studies into the reasons for violating academic integrity among students at Ukrainian institutions and factors influencing them. In order to implement effective academic integrity policies, Ukrainian higher education institutions need to have a solid base of research into the factors behind students reasons for academic dishonesty, including various personal, situational, and environmental ones and include an institutional and systemic review of academic integrity. However, representative results of studies conducted among students from the USA or other countries might seem, they should be utilized with a great caution when applied to Ukraine. Cross-national studies prove that students from different cultures and countries appear to have significantly different views on and attitudes toward cheating situations (ChudzickaCzupała, A., Lupina-Wegener, A., Hapon, N., 2013; Magnus, J. R., Polterovich, V. M., Danilov, D.L., Savvateev, A.V., 2002), that is why the factors and reasons for engaging in academic dishonesty practices in Ukrainian HEIs should be studied specifically for domestic students. A future study that should be conducted in Ukrainian HEIs, is how to more effectively consider academic integrity policies as they relate to international students studying in Ukrainian HEIs. Given that culture and country of origin have been measured to have an effect in American institutions, it would be valuable to study these effects in a Ukrainian setting.

Moving forward, Ukrainian institutions need to find a more effective medium for communicating their approaches to addressing and improving standards of academic integrity. This will assist in creating a generation of students more capable of integrating into the global market, and ultimately serves in the best interests of the institutions in the long run. We contend that Ukrainian institutions need to be more open in their communication and efforts to combat the absence of academic integrity, and should seek to create honor codes that best represent the unique nature of their student body and academic traditions of their institutions. 


\section{References}

1. Allmon, D.E., Page D., Roberts, R. (2000). Determinants of perception of cheating: Ethical orientation, personality, and demographics. Journal of Business Ethics, 23, 411-422.

2. Analitychna dovidka za rezultatamy doslidzhennia praktyk akademichnoi dobrochesnosti u vyshchykh navchalnykh zakladakh Ukrainy. Ministerstvo osvity i nauky Ukrainy. Instytut osvitnoi analityky (2016). Kyiv.

3. Angell, L. R. (2006). The relationship of impulsiveness, personal efficacy, and academic motivation to college cheating. College Student Journal, 40(1), 118-131.

4. Anderman, E. M. (2007). The effects of personal, classroom and school goal structures on academic cheating. In Eric M. Anderman \& Tamera B. Murdock (Eds.). Psychology of Academic Cheating. Burlington, MA: Elsevier Academic Press.

5. Bakirov, V.S. (2015). Akademichna kultura ukrayinskoho studenstva: osnovni chynnyky formuvannya ta rozvytku. Osnovni rezultaty doslidzhennya za proektom no. 49169. Available at: http://www.univer.kharkov.ua/images/redactor/news/2015-07-17/2015.pdf.

6. Ballantine, J., Larres, P. M. (2012). Perceptions of authorial identity in academic writing among undergraduate accounting students: Implications for unintentional plagiarism. Accounting Education, 21(3), 289-306.

7. Baum, J. J. (2005). CyberEthics: The new frontier. TechTrends, 49(6), 54-56.

8. Brown, B.S., Weible, R.J. \& Olmosk, K.E. (2010). Business School Deans on Student Academic Dishonesty: A Survey. College Student Journal, 44(2), 299-308.

9. Brown, D. L. (2002). Cheating Must Be Okay - Everybody Does It! Nurse Educator 27(1), 6-8.

10.Bruster, B. (2004). Cut and paste from cyberspace: Competency's changing face. Delta Kappa Gamma Bulletin, Summer, 38-40.

11.Callahan, D. (2004). The Cheating Culture: Why More Americans Are Doing Wrong to Get Ahead. Orlando, FL: Harcourt, Inc.

12.Chapman, K. \& Lupton, R. (2004). Academic dishonesty in a global educational market: A comparison of Hong Kong and American university business students. The International Journal of Educational Management, 18, 425-435.

13.Cheating Scandal at UVA Highlights the Need for Fairness and Due Process (2001) Retrieved from https://www.thefire.org/cheating-scandal-at-uva-highlights-the-need-for-fairness-and-due-process/.

14.Chudzicka-Czupała, A., Lupina-Wegener, A., Hapon, N. (2013). Students' attitude toward cheating in Switzerland, Ukraine and Poland. The New Educational Review, 32(2), 66-76.

15.Clariana, M. (2013). Personality, procrastination and cheating in students from different university degree programs. Electronic Journal of Research in Educational Psychology, 30, 452-472.

16.Cummings, R., Maddux, C. D., Harlow, S., \& Dyas, L. (2002). Academic Misconduct in Undergraduate Teacher Education Students and Its Relationship to Their Principled Moral Reasoning. Journal of Instructional Psychology, 29(4), 286-296.

17.Del Carlo, D. I, \& Bodner, G. M. (2003). Students' Perceptions of Academic Dishonesty in the Chemistry Classroom Laboratory. Journal of Research in Science Teaching, 41(1), 47-64.

18.Denisova-Schmidt, E. (2016) The global challenge of academic integrity. International Higher Education. 87, 4-6.

19.European Research Association (2013). Pravo na osvitu ta prava osvityan: teoriya i praktyka v Ukraini. Kyiv. Available at: http://www.irf.ua/files/ukr/programs/edu/ERA_Monitoring.pdf.

20.Fawzy, F. (2016). From speeches to PhD's: Politi- cians called out for copying. CNN Politics. 19th July 19.

21.Giluk, T.I., Postlethwaite, B.E. (2015). Big Five personality and academic dishonesty: A meta-analytic review. Personality and individual differences, 72, 59-67.

22.Grimes, Paul W., A. (2003). Cross-Cultural Analysis of Academic Dishonesty in High School Economics Classrooms. Available at SSRN: https://ssrn.com/abstract=410721.

23.Harding, T. S., Carpenter, D. D., Finelli, C. J., \& Passow, H. J. (2004). Does academic dishonesty relate to unethical behavior in professional practice? An exploratory study. Science and Engineering Ethics, 10, 311-324.

24.Harris, J. R. (1989). Ethical values and decision processes of male and female business students. Journal of Education for Business, 64(5): 234-238.

25.Hendershott, A. Drinen, P. \& Cross, M. (2000). Toward Enhancing a Culture of Academic Integrity. NASPA Journal, 37(4), 587-598.

26.Heuser, B.L. \& Drake T.A. (2011). Toward global academic ethics through accountability systems. Creating the Ethical Academy, Routledge, Abingdon. 
27.Hinman, L. M. (2002). Academic integrity and the World Wide Web. Computers and Society, 32(1), 33-42.

28.Iaboni, R. (2013). Harvard students forced to withdraw amid cheating scandal. Retrieved from https://edition.cnn.com/2013/02/01/us/massachusetts-harvard-cheating-scandal/.

29.International Student Survey (2017). The changing dynamics of international student recruitment, Hobsons. Available at: https://www.internationalstudentsurvey.com.

30.Jocoy, C. (2006). Plagiarism by Adult Learners Online: A case study in detection and remediation. The International Review of Research in Open and Distance Learning, 7(1), 1-17.

31.Jones, D. L. R. (2011). Academic dishonesty: are more students cheating? Business Communication Quarterly, 74(2), 141-150.

32.Jordan, A.E. (2001). College student cheating: The role of motivation, perceived norms, attitudes, and knowledge of institutional policy. Ethics \& Behavior, 11(3), 233-247.

33.Jordan, M. \& Belkin, D. (2016). Foreign students seen cheating more than domestic ones. Wall Street Journal. June 5. Available from: http://www.wsj. com/articles/foreign-students-seen-cheating-more- thandomestic-ones-1465140141.

34.Kisamore, J. L., Stone, T. H., \& Jawahar, I. M. (2007). Academic integrity: The relationship between individual and situational factors on misconduct contemplation. Journal of Business Ethics, 75(3), 381-394.

35.Klein, H. A., Levenburg, N. M., et al. (2007). Cheating during the college years: How do business school students compare? Journal of Business Ethics, 72(2), 197-206.

36.LaDuke, R. (2013) Academic dishonesty today, unethical practices tomorrow. Journal of Professional Nursing, 29(6), 402-406.

37.Langlais, P. J. (2006). Ethics for the next generation. Chronicle of Higher Education, 52(19), B11.

38.Lindsay, R. (2015). Academic dishonesty at Stanford: What compels elite students to cheat? Retrieved from https://www.csmonitor.com/USA/Education/2015/0329/Academic-dishonesty-at-Stanford-Whatcompels-elite-students-to-cheat.

39.Lucas, G. M., \& Friedrich, J. (2005). Individual differences in workplace deviance and integrity as predictors of academic dishonesty. Ethics \& Behavior, 15, 15-35.

40.Lupton, R. A., Chapman, K. J., Weiss, J. E. (2000). A Cross-National Exploration of Business Students' Attitudes, Perceptions and Tendencies toward Academic Dishonesty. Journal of Education for Business 75(4), 231-235.

41.Lyall, S. (2014). U.N.C. Investigation reveals athletes took fake classes. Retrieved from https://www.nytimes.com/2014/10/23/sports/university-of-north-carolina-investigation-reveals-shadowcurriculum-to-help-athletes.html?_r=0.

42.Macdonald, R., \& Carroll, J. (2006). Plagiarism - A complex issue requiring a holistic institutional approach. Assessment \& Evaluation in Higher Education, 31(2), 233-245.

43.Magnus, J. R., Polterovich, V. M., Danilov, D.L., Savvateev, A.V. (2002). Tolerance of Cheating: An Analysis across Countries. The Journal of Economic Education, 33, 125-35.

44. Marsden, H., Caroll, M. \& Neill, J. (2005). Who cheats at university? A self-report study of dishonest academic behaviours in a sample of Australian university students. Australian Journal of Psychology, 57(I), 1-10.

45.Martin, D. F. (2005). Plagiarism and technology: A tool for coping with plagiarism. Journal of Education for Business, 80(3), 149-152.

46.McCabe, D. L., \& Trevino, L. K. (1997). Individual and contextual factors on academic dishonesty: A multicampus investigation. Research in Higher Education, 38, 379-396.

47.McCabe, D. L., and Pavela, G. (2000). Some good news about academic integrity. Change, 32(5), 32-38.

48.McCabe, D. L., Trevino, L. K., and Butterfield, K. D. (2001). Cheating in academic institutions: A decade of research. Ethics \& Behavior, 11(3), 219-232.

49.McCabe, D. L., and Trevino, L. K. (2002). Honesty and honor codes. Academe, 88(1), 37- 41.

50.McCabe, D. L. (2005). Cheating among college and university students: A North American perspective. Journal of Educational Integrity, 1.

51.McCabe, D. L., Butterfield, K.D., \& Trevino, L. K. (2006). Academic dishonesty in graduate business programs: prevalence, causes, and proposed action. Academy of Management Learning \& Education, 5(3), 294-305.

52.Miller, A. D., Murdock, T. B., Anderman, E. M., \& Poindexter, A. L. (2007). Who are all these cheaters? Characteristics of academically dishonest students. Psychology of academic cheating. (pp. 9-32). Burlington, MA: Elsevier Academic Press.

53.Murdock, T.B., Miller, A., \& Kohlhardt, J. (2004). Effects of classroom context variables on high school students' judgments of the acceptability and likelihood of cheating. Journal of Educational Psychology, 96(4), 765-777. 
54.NCAA should punish the University of North Carolina for cheating scandal (2014). Retrieved from http://www.chicagotribune.com/news/opinion/editorials/ct-north-carolina-sports-scandal-edit-110820141107-story.html.

55.Nonis, S., \& Swift, C. O. (2001). An examination of the relationship between academic dishonesty and workplace dishonesty: A multicampus investigation. The Journal of Education for Business, 77, 69-77.

56.OECD (2017), OECD Reviews of Integrity in Education: Ukraine 2017, OECD Publishing, Paris.

57.Petress, K. C. (2003). Academic dishonesty: A plague on our profession. Education, 123(3), 624-627.

58.Pickard, J. (2006). Staff and student attitudes to plagiarism at University College Northampton. Assessment \& Evaluation in Higher Education, 31(2), 215-232.

59.Policy and Procedures for Student Academic Misconduct. University of Maryland Graduate School (UMBC Policy III-1.10.02). Available at: https://oue.umbc.edu/files/2015/09/iii-1.10.02.pdf.

60.Polotska, O. O. (2016). Analiz stanu obiznanosti studentiv klasychnoho universytetu z pytan akademichnoi ta naukovoi dobrochesnosti. Problemy inzhenerno-pedahohichnoi osvity, 50-51, 356-362.

61.Rabi, S. M., Patton, L. R., Fjortoft, N., \& Zgarrick, D. P. (2006). Characteristics, prevalence, attitudes, and perceptions of academic dishonesty among pharmacy students. American Journal of Pharmaceutical Education, 70(4).

62.Roig, M., \& Caso, M. (2005). Lying and Cheating: Fraudulent Excuse Making, Cheating, and Plagiarism. The Journal of Psychology: Interdisciplinary and Applied, 139(6), 485-494.

63.Romakin, V. V. (2010). Motyvatsii, perekonannia ta povedinka ukrainskykh i amerykanskykh studentiv bakalavratu shchodo norm akademichnoi kultury. Naukovi pratsi [Chornomorskoho derzhavnoho universytetu imeni Petra Mohyly kompleksu "Kyievo-Mohylianska akademiia"]. Ser.: Pedahohika. 136(123), 34-41.

64.Salgado, J. F., Moscoso, S., Sanchez, J. I., Alonso, P., Choragwicka, B., \& Berges, A. (2014). Validity of the five-factor model and their facets: The impact of performance measure and facet residualization on the bandwidth-fidelity dilemma. European Journal of Work and Organizational Psychology.

65.Schrimsher, R. H., Northrup, L.A., \& Alverson, S.P. (2011). A survey of Samford University students regarding plagiarism and academic misconduct. International Journal for Educational Integrity, 7(1), 3-17.

66. Solomon, J. (2015). What Syracuse's NCAA case revealed about academic fraud. Retrieved from https://www.cbssports.com/college-football/news/what-syracuses-ncaa-case-revealed-about-academic-fraud/.

67.Statistics of International Center for Academic Integrity. Retrieved from http://www.academicintegrity.org/icai/integrity-3.php.

68.Stechenko, O. V. (2016). Problema akademichnoi chesnosti v navchalnomu protsesi ta nautsi: dosvid Natsionalnoho medychnoho universytetu imeni O. O. Bohomoltsia. Medychna osvita, 3, 93-98.

69.Strengthening Academic Integrity in Ukraine Project (2016). Rezultaty doslidzhennia "Akademichna dobrochesnist: stan ta faktory vplyvu". Available at: http://www.saiup.org.ua/resursy/motyvatsiyastudentiv-navchannya-yak-vyznachalna-umova-akademichnoyi-dobrochesnosti-doslidzhennya/.

70.Student Guide to Academic Integrity Policies and Procedures. Bates College. Available at: http://www.bates.edu/student-affairs/files/2015/02/Student-Info-Sheet-Academic-Integrity-2016-17.pdf.

71.Synder, L. G., \& Cannoy, S. D. (2010). Business communication: Instructional strategies to prevent plagiarism. Business Education Forum, 65, 23-25.

72.Szabo, A., \& Underwood, J. (2004). Cybercheats: Is Information and Communication Technology fuelling academic dishonesty? Active Learning in Higher Education, 5(2), 180-199.

73.Vojak, C. (2007). What market culture teaches students about ethical behavior. Ethics and Education, 1(2), $177-195$.

74.Whitley, B. E. Jr. (1998). Factors associated with cheating among college students: A review. Research in Higher Education, 39, 235-274. 72. Whitley, B. E., Nelson, A. B., \& Jones, C. J. (1999). Gender differences in cheating attitudes and behaviors: A meta-analysis. Sex Roles, 41, 657-680.

75.Williams, K. M., Nathanson, C., \& Paulhus, D. L. (2010). Identifying and profiling scholastic cheaters: Their personality, cognitive ability, and motivation. Journal of Experimental Psychology: Applied, 16, 293-307.

76.Wood, J. A,, \& Longenecker, J. G. (1988). Ethical attitudes of students and business professionals: A study of moral reasoning. Journal of Business Ethics, 7, 249-257.

77.Zakon Ukrayiny Pro Osvitu [Law of Ukraine on Education]. Vidomosti Verhovnoyi Rady (VVR) 2017, №38-39, 380.

78.17 United States Code, $\$ 102$ (1990).

79.17 United States Code $§ 401,405$ (1988). 